\title{
Kompletowanie zespołu zadaniowego - mozaika ról
}

https://doi.org/10.33141/po.2005.04.08

\section{Stanisław Chełpa}

\section{Synergia w zespole - nie takie to proste}

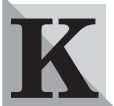

lasyczne badanie M. Ringelmanna [5], przeprowadzone na początku XX wieku, dobitnie wykazało, że uzyskanie efektu synergii w zespole zadaniowym nie jest rzeczą łatwą. W przypominanym badaniu polecano ludziom ciagnaćc linę. Najpierw zadanie to wykonywane było pojedynczo przez poszczególnych uczestników badań, później przez utworzone przez nich zespoły. Rozpoznanie indywidualnej siły, z jaką napinały linę badane osoby, pozwoliło na porównanie sumy ich potencjalnego „wysiłku", który mógłby być wkładany w realizację zadania z rzeczywiście wydatkowanym podczas zespołowego wykonywania tego zadania. Okazało się, że uzyskiwany efekt synergii zespołowej był zawsze mniejszy niż się spodziewano. Zespoły złożone z dwóch osób ciągnęły linę, wkładając w realizację tego zadania $93 \%$ swoich możliwości. Jeśli współpracowali ze sobą trzej ludzie, pożytkowali oni już tylko $85 \%$ swojego indywidualnego potencjału. Jednak najbardziej spektakularny wynik odnotowano w zespołach ośmioosobowych. Wykorzystywały one bowiem jedynie 49\% tkwiącego w nich potencjału.

$\mathrm{Z}$ badania tego wynika, że uzyskiwana przez zespół synergia nie jest zwykłą matematyczną sumą możliwości indywidualnych, jakimi dysponują poszczególni jego członkowie. Widoczna stała się też inna ważna prawidłowość. Okazało się mianowicie, że wzrost liczebności zespołu łączy się ze zmniejszaniem się poziomu wykorzystania potencjału zawodowego tkwiacego w poszczególnych członkach zespołu zadaniowego. Tak więc, żeby zwiększyć siłę zespołu zdecydowanie mało efektywnym zabiegiem może być dodawanie do niego coraz to nowych członków, choćby dysponowali oni nadzwyczajnymi możliwościami zawodowymi. Osiagnnięty rezultat nie musi wcale prowadzić do podwyższenia sprawności pracy zespołowej. Prędzej już ulegną rozproszeniu i zmarnują się możliwości zawodowe wnoszone do zespołu przez nowych jego członków. Czemu scenariusz ten wydaje się prawdopodobny?

Powodów tego stanu rzeczy można doszukiwać się w procesach związanych ze społecznym porównywaniem się pracowników wchodzących w skład zespołu zadaniowego. Stą też tak ważne jest rozpoznanie osób tworzacych silne i słabe ogniwa tego zespołu. One to bowiem wyznaczają granice pola pracy zespołowej wysiłku i zaangażowania wkładanego w zadania realizowane przez ten zespół. Nowo pozyskani pracownicy obserwując innych i ich codzienną pracę - kierując się zasadą równości - dopasowują własną motywację do „starych” członków zespołu. Jednak to nie kon-
Przegląd Organizacji, Nr 4 (783), 2005, ss. 34-37 www.przegladorganizacji.pl Towarzystwo Naukowe Organizacji i Kierownictwa (TNOiK) formizm wyznacza ich zachowania, ale zasada ekonomii podejmowanych działań. Dlatego właśnie szczególne znaczenie ma rozpoznanie słabego ogniwa w kierowanym zespole. Tempo marszu - jak mawiali moi dowódcy w wojsku - nie wyznacza wcale najsprawniejszy żołnierz, ale ten faktycznie najsłabszy. Wiedzę tę musiał uwzględniać i jakoś sobie $\mathrm{z}$ nią radzić każdy przełożony. Można więc bez większego ryzyka przyjąć, że to właśnie najmniej efektywny członek zespołu może mieć największy wpływ na motywację całego zespołu. On bowiem wyznacza dolny próg ujawnianej w pracy motywacji, koniecznej i akceptowanej przez organizację, tzn. przez jej „fizycznie namacalnego” reprezentanta - kierownika zespołu zadaniowego.

Budując zespół pracowniczy lub dokonując jego rekonstrukcji warto zatem zdawać sobie sprawę z tego, kto (z imienia i nazwiska) stanowi w nim najsłabsze ogniwo. Być może wiedza ta - choć bolesna (zwłaszcza u empatycznego kierownika) - wyznaczy pierwsze kroki planowanego przez niego procesu. „Niekiedy, aby wnieść się wyżej - jak twierdzi M. Bauer [2, s. 143] - trzeba zrzucić balast". Decyzje kadrowe należą i ciągle będą w zakresie kompetencji kierowniczych. Szef zespołu decyduje o pracy powierzonych mu ludzi, ich być albo nie być w zespole. Chodzi o to tylko, by decyzje te wynikały z przesłanek merytorycznych i uwzględniały aktualną sytuację, w jakiej znajduje się zespół oraz warunki jego istnienia w dalszej perspektywie czasowej.

\section{Role deficytowe i nadmiarowe}

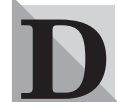

la skuteczności zadań realizowanych przez zespół pracowniczy ważne jest, by zespół ten - traktowany jako całość - dysponował odpowiednim potencjałem. Jednym z jego wyznaczników są struktury ról preferowanych i odrzucanych przez poszczególnych członków zespołu. Tworzą one zbiorczy profil ról danego zespołu zadaniowego. Każdy zespół powinien być pod tym kątem zdiagnozowany. Rozpoznanie to pozwala na odpowiednią kompozycję zespołu. Można wykluczyć z niego pracowników powielających preferencje odnoszące się jedynie do pewnego tylko typu ról, powodujace nadmierne spiętrzenie się tych ról, a w efekcie wąską specjalizację zespołu, małą jego elastyczność i niezaradność w nowych, zmieniajacych się warunkach pracy. Na zwolnione miejsca należy wprowadzić innych ludzi, którzy uzupełniliby skład zespołu, podejmując i odgrywając role potrzebne zespołowi, dotąd odrzucane i będące w deficycie. W ten sposób trzeba komponować zespoły pracownicze i zmieniać ich składy w zależności od stawianych mu zadań - teraz i w przyszłości. Zespół, je- 
Tab. 1. Struktura preferencji ról ujawniana przez polską kadrę kierowniczą

\begin{tabular}{|l|c|c|c|}
\hline \multicolumn{1}{|c|}{ Role grupowe } & Średnia & Odchylenie standardowe & Pozycja w strukturze \\
\hline Praktyczny organizator & 11,90 & 4,40 & $\mathbf{1}$ \\
\hline Naturalny lider & 7,65 & 4,76 & $\mathbf{7}$ \\
\hline Człowiek akcji & 11,38 & 5,60 & $\mathbf{2}$ \\
\hline Siewca idei & 5,16 & 3,59 & $\mathbf{8}$ \\
\hline Człowiek kontaktów & 7,97 & 3,51 & $\mathbf{5}$ \\
\hline Sędzia & 9,43 & 4,12 & $\mathbf{4}$ \\
\hline Człowiek grupy & 7,77 & 4,45 & $\mathbf{6}$ \\
\hline Perfekcjonista & 9,73 & 4,17 & $\mathbf{3}$ \\
\hline
\end{tabular}

Źródło: opracowanie własne.

Tab. 2. Charakterystyka ról podejmowanych w zespole zadaniowym

\begin{tabular}{|c|c|c|c|}
\hline Możliwe role & Pozytywy & Negatywy & $\begin{array}{l}\text { Ukierunkowa- } \\
\text { nie roli }\end{array}$ \\
\hline $\begin{array}{l}\text { Perfekcjonista } \\
\text { (skrupulatny } \\
\text { wykonawca) }\end{array}$ & $\begin{array}{l}\text { Staranny, uporządkowany, sumienny, } \\
\text { drobiazgowy, nastawiony na doprowadza- } \\
\text { nie rozpoczętych działań do ich zakończe- } \\
\text { nia, pryncypialny, zdyscyplinowany }\end{array}$ & $\begin{array}{l}\text { Skłonny do zamartwiania się szczegółami, } \\
\text { przeżywający długotrwałe napięcia zwią- } \\
\text { zane z realizacją pracy, gubiący ogląd wy- } \\
\text { konywanej pracy z perspektywy całości, } \\
\text { niechętnie dzielący się zadaniami z inny- } \\
\text { mi }\end{array}$ & $\begin{array}{l}\text { Nastawienie } \\
\text { na zadania }\end{array}$ \\
\hline $\begin{array}{l}\text { Sędzia } \\
\text { (krytyk warto- } \\
\text { ściujący) }\end{array}$ & $\begin{array}{l}\text { Rozsądny, ostrożny, posiadający umiejęt- } \\
\text { nośc merytorycznej - wypranej z emocji - } \\
\text { oceny innych ludzi i wysuwanych przez } \\
\text { nich propozycji działań, rzeczowy }\end{array}$ & $\begin{array}{l}\text { Przeciętne umiejętności inspirowania i mo- } \\
\text { tywowania innych, nadmiernie krytyczny, } \\
\text { skłonny do arbitralności, dystansujący się } \\
\text { wobec ocenianej działalności oraz ludzi, } \\
\text { skrywający emocje, mało energiczny }\end{array}$ & $\begin{array}{l}\text { Nastawienie } \\
\text { na zadania }\end{array}$ \\
\hline $\begin{array}{l}\text { Człowiek akcji } \\
\text { (lokomotywa) }\end{array}$ & $\begin{array}{l}\text { Dynamiczny, odważny, stawiający grupie } \\
\text { wyzwania, nastawiony na przezwycięża- } \\
\text { nie samozadowolenia i inercji }\end{array}$ & $\begin{array}{l}\text { Skłonny do prowokowania innych, irytu- } \\
\text { jący, chwiejący poczuciem bezpieczeństwa, } \\
\text { łatwo denerwujący się i impulsywny }\end{array}$ & $\begin{array}{l}\text { Nastawienie } \\
\text { na zadania }\end{array}$ \\
\hline $\begin{array}{l}\text { Siewca idei } \\
\text { (myśliciel) }\end{array}$ & $\begin{array}{l}\text { Indywidualista, postępowy, niekonwencjo- } \\
\text { nalny w zachowaniu i myśleniu, kreatyw- } \\
\text { ny, posiadający wyobraźnię, entuzjasta }\end{array}$ & $\begin{array}{l}\text { Skłonny do pomijania szczegółów, naru- } \\
\text { szający status quo, wzbudzający niepokój, } \\
\text { nadwrażliwy na krytykę, nadmiernie za- } \\
\text { jęty nowymi ideami i zaniedbujący prak- } \\
\text { tykę }\end{array}$ & $\begin{array}{l}\text { Nastawienie } \\
\text { na zadania }\end{array}$ \\
\hline $\begin{array}{l}\text { Człowiek } \\
\text { kontaktów } \\
\text { (poszukiwacz } \\
\text { źródeł) }\end{array}$ & $\begin{array}{l}\text { Dysponujący umiejętnościami interperso- } \\
\text { nalnymi, ciekawy świata, komunikatyw- } \\
\text { ny, pragmatyczny, entuzjastyczny }\end{array}$ & $\begin{array}{l}\text { Szybko tracący zainteresowanie realizo- } \\
\text { wanymi zadaniami, unikający sytuacji } \\
\text { konfliktowych, nadmiernie optymistyczny }\end{array}$ & $\begin{array}{l}\text { Nastawienie } \\
\text { na ludzi }\end{array}$ \\
\hline $\begin{array}{l}\text { Człowiek grupy } \\
\text { (dusza zespołu) }\end{array}$ & $\begin{array}{l}\text { Nastawiony na potrzeby ludzi, lojalny, } \\
\text { łagodny i empatyczny, potrafiący wzbu- } \\
\text { dzać „ducha zespołu”, zapobiegający kon- } \\
\text { fliktom, dyplomatyczny }\end{array}$ & $\begin{array}{l}\text { Mało zdecydowany w sytuacjach kryzyso- } \\
\text { wych, uległy, mający kłopoty ze zdecydo- } \\
\text { waną oceną pracy innych }\end{array}$ & $\begin{array}{l}\text { Nastawienie } \\
\text { na ludzi }\end{array}$ \\
\hline $\begin{array}{l}\text { Praktyczny } \\
\text { organizator } \\
\text { (realizator) }\end{array}$ & $\begin{array}{l}\text { Trzymający się wypracowanych i spraw- } \\
\text { dzonych standardów, potrafiący struktu- } \\
\text { ryzować zachowania własne i cudze, obo- } \\
\text { wiązkowy, praktyczny, wzbudzający zau- } \\
\text { fanie }\end{array}$ & $\begin{array}{l}\text { Mało elastyczny, konserwatywny, niechęt- } \\
\text { ny wobec zmian, asekuracyjny }\end{array}$ & $\begin{array}{l}\text { Nastawienie na } \\
\text { zadania i ludzi }\end{array}$ \\
\hline $\begin{array}{l}\text { Naturalny lider } \\
\text { (koordynator) }\end{array}$ & $\begin{array}{l}\text { Pewny siebie, spokojny, zdyscyplinowany, } \\
\text { dominujący, potrafiący dostrzec potencjał } \\
\text { tkwiący w innych ludziach, skupiony na } \\
\text { celach, posiadający duże umiejętności in- } \\
\text { terpersonalne }\end{array}$ & $\begin{array}{l}\text { Przeciętny poziom sprawności intelektu- } \\
\text { alnej, może być spostrzegany jako mani- } \\
\text { pulator }\end{array}$ & $\begin{array}{l}\text { Nastawienie na } \\
\text { zadania i ludzi }\end{array}$ \\
\hline
\end{tabular}

Źródło: opracowano na podstawie: [1, 3, 6, 8].

W nawiasie podane są inne nazwy ról grupowych spotykane w polskojęzycznej literaturze. Podejmowane role mogą być ukierunkowane jednostronnie - na zadania („liczy się przede wszystkim praca”) lub na ludzi („najważniejsze są potrzeby członków zespołu i atmosfera w nim panująca”) bądź też dwustronnie - harmonizujące orientację zadaniową z interpersonalną. 
śli chce przetrwać na wewnątrzorganizacyjnym rynku pracy, musi się zmieniać. Stąd wynika inna, ważna konstatacja, skierowana bezpośrednio do pracowników. Pamiętać oni powinni, że przynależność do konkretnego zespołu jest w mniejszym lub większym stopniu, ale zawsze tylko doraźna. Świadomość tej wiedzy może skutecznie naruszać potrzebę bezpieczeństwa pracowników, a także oddziaływać destrukcyjnie na ich lojalność wobec organizacji i chęć identyfikowania się $\mathrm{z}$ nią. Utrata miejsca $\mathrm{w}$ zespole zadaniowym nie powinna więc łączyć się ze zwolnieniem, ale poszukiwaniem nowej pracy, w innym zespole zadaniowym. Organizacja powinna też wyposażać pracownika w nowe kwalifikacje, łożąc na jego szkolenia zawodowe, najlepiej umiejętności uniwersalnych, transorganizacyjnych, możliwych do wykorzystania w wielu różnych instytucjach. W ten sposób, gdyby doszło do sytuacji utraty pracy w ogóle, pracownik ma szansę łatwiejszego jej znalezienia na zewnątrzorganizacyjnym rynku pracy.

Wracajac do zasadniczego nurtu prowadzonych tu rozważań, trzeba odpowiedzieć na pytanie, jakiego typu role w grupach zadaniowych sa nadmiernie reprezentowane, a których ról pracownicy nie chcą się podejmować? Wyobrażenie na ten temat dają badania, w których uczestniczyli polscy kierownicy [4]*). Wynika z nich (zob. tab. 1), że badani chętnie odgrywają w zespołach zadaniowych następujące role: praktycznego organizatora (strukturyzatora zachowań własnych i cudzych), człowieka akcji (stymulatora innych poprzez stawianie wyzwań) oraz perfekcjonisty (pedanta zadaniowego). Do ról przez nich odrzucanych można zaliczyć siewcę idei (innowatora) oraz naturalnego lidera (przywódcy).

Można zauważyć (zob. tab. 2), że kierownicy w sposób zdecydowany odnoszą się do ról zorientowanych zadaniowo, albo je preferując, albo też odrzucając. Prawidłowość ta nie dotyczy już ról grupowych ogniskujących się na społecznej stronie wykonywanej pracy. To przejawione przez kierowników niedocenianie innych ludzi może budzić uzasadniony niepokój. Wszak powinni oni pracować wraz z innymi ludźmi, dbając o zaspokojenie ich potrzeb i odpowiednią atmosferę w kierowanym zespole, i to wcale nie dlatego, że wymaga się od nich, by byli niczym anioły, ale z tego pragmatycznego powodu, że wtedy zespół ma większe osiagnięcia i dobrze rokuje na przyszłość.

Obraz ten uzupełniają inne otrzymane w cytowanym badaniu dane [4]. Wynika $\mathrm{z}$ nich kilka prawidłowości, na które trzeba zwrócić uwagę. Okazało się, że wśród kierowników:

- nasila się tendencja do odgrywania roli sędziego przyglądającego się z dystansu, chłodnego emocjonalnie, ale merytorycznego i bezstronnego recenzenta poczynań innych członków zespołu;

- obniża się skłonność do podejmowania roli człowieka grupy - troszczącego się o sprawy innych, budującego klimat i ducha zespołu;

- trwała jest niechęć do odgrywania roli siewcy idei poszukującego okazji do innowacji i twórczych rozwiązań, otwartego na zmiany istniejącego stanu rzeczywistości.

Z przedstawionych rezultatów badań można wyciągnąć wniosek, że rolami bardziej preferowanymi są role nastawione na pracę w stabilnym, w miarę nie zmieniającym się otoczeniu. Role zadaniowe już, łączące w sobie aktywność innowacyjną (siewca idei) oraz zindywidualizowane podejście do innych - odkrywanie posiadanych przez nich talentów i ich pożytkowanie (naturalny lider), a ponadto niezbędne w zmieniajacym się otoczeniu wewnątrz- i zewnątrzorganizacyjnym, są niechętnie podejmowane lub wręcz odrzucane. Pojawia się też tendencja do lekceważenia tzw. społecznej strony wykonywanej w zespole pracy. Wszystko to nie nastraja do optymizmu.

Nie wiadomo dokładnie, jakie role preferują, a jakich nie chca podejmować szeregowi członkowie zespołów zadaniowych. Można się jednak spodziewać, że będą odzwierciedlać tendencje ujawniane przez osoby znaczące w zespole („układ odniesienia”), czyli przez jego kierowników. Z drugiej strony, można mieć jednak nadzieję, iż są w zespole opozycjoniści, którzy z chęcią będą odgrywać inne role niż kierownicy, zmieniajac w ten sposób charakter pracy całego zespołu. Będą oni pełnić wobec kierownika funkcję „drugiej połówki", dobrze go uzupełniajac. Problem ten wymaga jednak rozpoznania empirycznego, nie tylko przez teoretyków, ale przede wszystkim właśnie przez praktyków zajmujących się kierowaniem ludźmi i zarządzaniem kadrami.

\section{Grupowy profil ról odgrywanych w zespole}

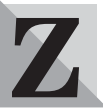

daniem wielu badaczy (np. $[1,3,9,10])$ zespół zadaniowy nie powinien być jednorodny pod względem preferencji jego członków do podejmowania czy też odrzucania ról grupowych. Role grupowe powinny się równoważyć dzięki zachodzeniu między nimi relacji komplementarności. Wtedy zespół taki może realizować zróżnicowane treściowo zadania. Jednorodność zadań sprzyja więc homogeniczności zespołu pod względem charakteru preferowanych przez jego członków ról grupowych.

Uwzględniając powyższe S.G. Fisher i T.A. Hunter [7] zaproponowali podział ról grupowych na cztery, wzajemnie dopełniające się pary. Sa nimi: praktyczny organizator i perfekcjonista, naturalny lider i człowiek akcji, siewca idei i sędzia oraz człowiek kontaktów i człowiek grupy. Podaną propozycję można dość łatwo poddać krytyce, ponieważ niezbyt jasne wydają się racje takiego dwójkowego doboru ról. Wynika to zapewne ze złożoności opisu i różnorodnych, nie zawsze bezpośrednio przystawalnych do siebie, wymiarów behawioralnych poszczególnych ról. W to miejsce można zaproponować inne zestawienie ról grupowych. I tak, biorąc pod uwagę pryncypializm (i jego odwrotność - pragmatyzm) uzupełniającą się parę tworzą perfekcjonista i człowiek kontaktów. Kolejna para: praktyczny organizator i człowiek akcji jest różnicowana skłonnością do podejmowania ryzyka. Umiejętność radykalnego oceniania wkładu innych ludzi w realizowane zadania determinuje związek komplementarny między sędzią a człowiekiem grupy. Zostają jeszcze siewca idei i naturalny lider, role do siebie $\mathrm{w}$ dużym stopniu podobne, to co je różni można sprowadzić do większego nastawienia na zadania w pierwszym przypadku, zaś bardziej nastawienia na ludzi - w drugim.

Na role grupowe podejmowane przez pracowników można spojrzeć także przez pryzmat zachodzącej mię- 
Tab.3.Macierzrólwchodzących wharmonijnąkooperację

\begin{tabular}{|c|c|c|c|c|c|c|c|c|}
\hline & $\begin{array}{l}\text { Praktyczny } \\
\text { organizator }\end{array}$ & \begin{tabular}{|c|}
$\begin{array}{c}\text { Naturalny } \\
\text { lider }\end{array}$ \\
\end{tabular} & $\begin{array}{c}\text { Człowiek } \\
\text { akcji }\end{array}$ & \begin{tabular}{|c} 
Siewca \\
idei
\end{tabular} & $\begin{array}{c}\text { Człowiek } \\
\text { kontaktów }\end{array}$ & Sędzia & $\begin{array}{c}\text { Człowiek } \\
\text { grupy }\end{array}$ & Perfekcjonista \\
\hline Perfekcjonista & $\mathrm{X}$ & & $\mathrm{X}$ & $\mathrm{X}$ & & & & \\
\hline Człowiek grupy & & & & $\mathrm{X}$ & & & & \\
\hline Sędzia & $\mathrm{X}$ & $\mathrm{X}$ & & & & & & \\
\hline $\begin{array}{l}\text { Człowiek } \\
\text { kontaktów }\end{array}$ & & & $\mathrm{X}$ & & & & & \\
\hline Siewca idei & & $\mathrm{X}$ & & & & & & \\
\hline Człowiek akcji & $\mathrm{X}$ & & & & & & & \\
\hline Naturalny lider & $\mathrm{X}$ & & & & & & & \\
\hline
\end{tabular}

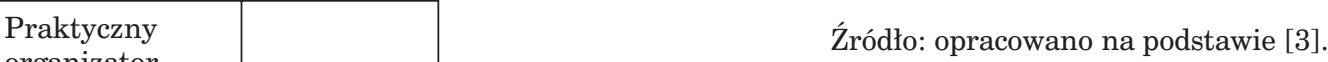

organizator

Role kooperatywne zaznaczono „X”.

Tab. 4. Macierz ról konfliktogennych

\begin{tabular}{|c|c|c|c|c|c|c|c|c|}
\hline & \begin{tabular}{|l|} 
Praktyczny \\
organizator
\end{tabular} & $\begin{array}{c}\text { Naturalny } \\
\text { lider }\end{array}$ & $\begin{array}{c}\text { Człowiek } \\
\text { akcji }\end{array}$ & \begin{tabular}{|c|}
$\begin{array}{c}\text { Siewca } \\
\text { idei }\end{array}$ \\
\end{tabular} & \begin{tabular}{|c|} 
Człowiek \\
kontaktów
\end{tabular} & Sędzia & $\begin{array}{c}\text { Człowiek } \\
\text { grupy }\end{array}$ & Perfekcjonista \\
\hline Perfekcjonista & & & & & $\mathrm{X}$ & $\mathrm{X}$ & & \\
\hline Człowiek grupy & & & $\mathrm{X}$ & & $\mathrm{X}$ & & & \\
\hline Sędzia & & & $\mathrm{X}$ & $\mathrm{X}$ & & & & \\
\hline $\begin{array}{l}\text { Człowiek } \\
\text { kontaktów }\end{array}$ & $\mathrm{X}$ & & $\mathrm{X}$ & $\mathrm{X}$ & & & & \\
\hline Siewca idei & $\mathrm{X}$ & & $\mathrm{X}$ & & & & & \\
\hline Człowiek akcji & & $\mathrm{X}$ & & & & & & \\
\hline Naturalny lider & & & & & & & & \\
\hline
\end{tabular}

Praktyczny

organizator

dzy nimi tendencji do kooperacji oraz ich konfliktogenności. Członkowie zespołu preferujący określone role grupowe będą łatwiej współdziałali z innymi członkami w zależności od tego, jakich ról chętnie się oni podejmują i odgrywaja (zob. tab. 3). Dobrej współpracy będa towarzyszyły wówczas rodzace się przyjazne wzajemne stosunki. Czy zawsze jednak przyjemna atmosfera w zespole gwarantuje odpowiednie jego wyniki, czy wszyscy jego członkowie muszą darzyć się sympatią. Wydaje się, że konflikt ukryty - czasem nawet jawny - między niektórymi członkami zespołu wykonywanej przez nich pracy nie zaszkodzi. Może nawet dopomóc w osiągnięciu lepszych rezultatów, dynamizując panujace relacje, kreujac rywalizacje wewnątrzzespołową oraz przeciwdziałając inercji zespołu i samozadowoleniu jego członków. Role, które łaczy potencjalny spór, co do racji nadrzędnych istnienia zespołu, stylu pracy mogą więc spotkać się w jednym zespole zadaniowym (zob. tab. 4). Nie powinna to być kwestia przypadku, ale świadomego wyboru. Czy prowokowany w ten sposób konflikt okaże się konstruktywny, to jest już sprawa kierownika takiego zespołu.

dr hab. Stanistaw Chetpa Katedra Zarzadzania Kadrami Akademii Ekonomicznej we Wrocławiu
Źródło: opracowano na podstawie [3]. Role konfliktogenne zaznaczono „X”.

*) Badania przeprowadzono w sześciu przedsiębiorstwach przemysłowych w latach 1994-1997. Uczestniczyło w nich 455 kierowników średniego i najniższego szczebla zarządzania.

BIBLIOGRAFIA

[1] BALDERSON S.J., BRODERICK A.J., Behaviour in Teams: Exploring Occupational and Gender Differences, „Journal of Managerial Psychology" 1996, nr 5.

[2 BAUER M., Templariusze. Mity i rzeczywistość, Wydawnictwo Dolnoślaskie, Wrocław 2004.

[3] BELBIN R.M., Twoja rola w zespole, Gdańskie Wydawnictwo Psychologiczne, Gdańsk 2003.

[4] CHEŁPA S., Kwalifikacje kadr kierowniczych przedsiębiorstw przemystowych. Kierunki i dynamika zmian, Wydawnictwo Akademii Ekonomicznej, Wrocław 2003.

[5] DASZKOWSKI J., Wptyw pracy grupowej na wysitek w realizacji zadań, Ossolineum, Wrocław 1988.

[6] DULEWICZ V., A Validation of Belbin's Team Roles from 16PF and OPQ Using Bosses' Ratings of Competence, „Journal of Occupational and Organizational Psychology" 1995, $\mathrm{nr} 2$.

[7] FISHER S.G., HUNTER T.A., The Structure of Belbin's Team Roles, „Journal of Occupational and Organizational Psychology” $1998, \mathrm{nr} 3$

[8] KOŻUSZNIK B., Metody doskonalenia kierowania, [w:] Psychologia $w$ pracy menedzera, red. B. KOŻUSZNIK, Wydawnictwo Uniwersytetu Slaskiego, Katowice 1994.

[9] MAKIN P., COOPER C., COX C., Organizacje a kontrakt psychologiczny. Zarzadzanie ludźmi w pracy, Wydawnictwo Naukowe PWN, Warszawa 2000.

[10] WITKOWSKI S.A., Dobór do pracy zespołowej - niedoceniany aspekt zarzadzania potencjatem pracowniczym, [w:] Zarzadzanie kadrami. Perspektywy badawcze i praktyka, red. T. LISTWAN, Wydawnictwo Akademii Ekonomicznej, Wrocław 2000. 